\title{
LIG3 wt Allele
}

National Cancer Institute

\section{Source}

National Cancer Institute. LIG3 wt Allele. NCI Thesaurus. Code C116586.

Human LIG3 wild-type allele is located within $17 q 11.2-q 12$ and is approximately $25 \mathrm{~kb}$ in length. This allele, which encodes DNA ligase 3 protein, plays a role in DNA repair. 